МЕНЕДЖМЕНТ ОРГАНІЗАЦЙ І АДМІНІСТРУВАННЯ

\author{
УДК 338.5:656.2
}

\title{
ДЕЯКІ АСПЕКТИ УПРАВЛІННЯ ВИТРАТАМИ НА ОСНОВІ ЕТАЛОННОГО ПІДХОДУ У СФЕРІ ЗАЛІЗНИЧНИХ ПЕРЕВЕЗЕНЬ
}

\author{
Магістрант С.Ю. Архіпкіна \\ НЕКОТОРЫЕ АСПЕКТЫ УПРАВЛЕНИЯ РАСХОДАМИ НА ОСНОВЕ ЭТАЛОННОГО \\ ПОДХОДА В СФЕРЕ ЖЕЛЕЗНОДОРОЖНЫХ ПЕРЕВОЗОК
}

\section{Магистрант С.Ю. Архипкина
SOME ASPECTS OF COST MANAGEMENT BASED ON THE REFERENCE APPROACH IN THE FIELD OF RAILWAY TRANSPORT

Master's Student S.Y. Arkhipkina

У статті розглянуто проблему вдосконалення методів управління експлуатаційними витратами. Вона є актуальною, потребує подальших теоретичних і прикладних досліджень та повинна вирішуватися в загальному контексті економічного управління залізничним транспортом. При одних і тих самих розмірах перевезень величина витрат залізниць може коливатися в досить широких межах залежно від того, яка робота затрачається для виконання иих перевезень. Таким чином, можна говорити про залежність витрат від розмірів перевезень тільки в тих випадках, коли розміри руху зростають у повній відповідності до збільшення перевезень, тобто коли всі фактори, крім вантажообігу, залишаються постійними.

Ключові слова: управління витратами, залізничні перевезення, ефективність, собівартість перевезень.

В статье рассмотрена проблема совершенствования методов управления эксплуатаџионными затратами. Она актуальна, требует дальнейших теоретических и прикладных исследований и долюна решаться в общем контексте экономического управления железнодорожным транспортом. При одних и тех же размерах перевозок величина расходов железных дорог может колебаться в достаточно широких пределах в зависимости от того, какая работа затрачивается для выполнения этих перевозок. Таким образом, можно говорить о зависимости расходов от размеров перевозок только в тех случаях, когда размеры движения возрастают в полном соответствии с увеличением перевозок, то есть когда все факторы, кроме грузооборота, остаются постоянными.

Ключевые слова: управление затратами, железнодорожные перевозки, эффективность, себестоимость перевозок.

The challenge of improving management practices operating costs is relevant, requires further theoretical and applied research and must be addressed in the overall context of economic governance rail. At the same amounts transportation costs railways value can vary within wide limits depending on the kind of work spent to perform such transportation. Thus, we can talk about dependence on the size of transport costs only in cases where the size of the movement grow in full accordance with the increase of traffic, ie, when all factors other than turnover, remain constant. This implies an important practical conclusion: the cost of transportation does not "need" to grow according to the percentage identified dependent costs with an increase in traffic. Skillful management of all factors that affect the operating costs and the cost should minimize the increase.

Keywords: cost management, rail transportation, efficiency, cost of transportation. 
Вступ. Проблема вдосконалення методів управління експлуатаційними витратами $\epsilon$ актуальною, потребує подальших теоретичних і прикладних досліджень i повинна вирішуватися в загальному контексті економічного управління залізничним транспортом. При одних і тих же розмірах перевезень величина витрат залізниць може коливатися в досить широких межах залежно від того, яка робота затрачається для виконання цих перевезень. Таким чином, можна говорити про залежність витрат від розмірів перевезень тільки в тих випадках, коли розміри руху зростають в повній відповідності до збільшення перевезень, тобто коли всі фактори, крім вантажообігу, залишаються постійними. 3 цього випливає важливий практичний висновок: витрати перевезень зовсім не «повинні» зростати згідно 3 виявленим відсотком залежних витрат при збільшенні обсягу перевезень. Вміле керування всіма факторами, що впливають на експлуатаційні витрати і собівартість, має мінімізувати це зростання $[1,2]$.

Визначення мети та задачі дослідження. Метою дослідження $\epsilon$ розроблення процесу застосування організаційнофункціональної системи управління витратами у сфері залізничних перевезень. У теорії і на практиці регулювання собівартості, як правило, акцентувалася увага на впливі якісних показників використання рухомого складу на собівартість залежній від обсягів роботи частині. Недолік такого підходу полягає у «виведенні» умовно-постійної частини собівартості (яка превалює в умовах стабільних транспортних потужностей) за межі технологічного регулювання. Досвід калькулювання собівартості за видами перевезень, повідомлення й тяги показує, що не тільки залежні, але й умовно-постійні витрати вдається обгрунтовано пов'язати 3 тими чи іншими об'ємними вимірювачами транспортної роботи, а отже, і з якісними показниками.

Основна частина дослідження. Таким чином, не заперечуючи економічного значення ділення експлуатаційних витрат і собівартості перевезень на залежні й умовно-постійні, при їх регулюванні слід акцентувати увагу саме на умовному характері незалежності частини витрат від обсягу роботи i, отже, зробити висновок, який підтверджується практикою економічних розподілів інструментів управління собівартістю перевезень, конкретизувати мету цього управління. Як правило, під оптимізацією собівартості перевезень розуміють ії мінімізацію. 3 одного боку, такий підхід цілком обгрунтований, оскільки зниження собівартості дає змогу встановлювати більш конкурентоспроможні тарифи на перевезення, за інших рівних умов забезпечує підвищення рентабельності перевезень і можливість додаткових інвестицій. Проте абсолютно очевидно, що мінімізація собівартості не може бути єдиним чи головним критерієм ефективності перевізної діяльності. Наприклад, використання рефрижераторних вагонів для перевезення швидкопсувних вантажів замість критих або обладнання кондиціонерами пасажирського рухомого складу збільшує собівартість перевезень, проте це доцільно при певних умовах. Критерієм ефективності управлінських рішень $€$ не мінімізація собівартості, а перевищення граничних доходів над граничними витратами для кожної конкретної одиниці продукції (виробничої операції) та забезпечення прийнятного співвідношення між собівартістю i прибутковістю в цілому. Саме в цьому випадку вдається оптимізувати фінансові результати діяльності.

Укрупнений алгоритм комплексного планування результатів перевізної діяльності, розроблений для сучасних умов, показаний на рисунку.

Вимоги до якості перевезень вантажів визначаються як Статутом залізничного транспорту і правилами перевезень вантажів, так $\mathrm{i}$ якісними параметрами попиту на перевезення 3 боку конкретних клієнтів, які акумулюються СФТО.

На основі цих вимог повинні визначатися якісні показники експлуатаційної роботи i технічних засобів та обсяг перевезень, а потім видаткові й прибуткові показники.

Якщо співвідношення собівартості і прибутковості не задовільне, повинно проводитися коригування якісних показників.

Наприклад, на основі вимог вантажовласників до терміновості доставки вантажу можуть бути визначені значення обороту вагона і конкретні параметри графіка руху, що дасть змогу забезпечити максимальний обсяг перевезень. У той же час в існуючих умовах прискорення обігу вагона пов'язане 3 додатковими витратами на утримання маневрових локомотивів, збільшення чисельності працівників ПТО станцій і т. д. 


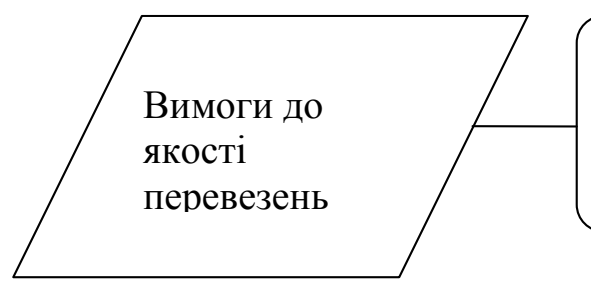

Розрахунок якісних показників експлуатаційної роботи і параметрів технічних засобів відповідних необхідному рівню якості перевезень

Визначення об'ємів перевезень
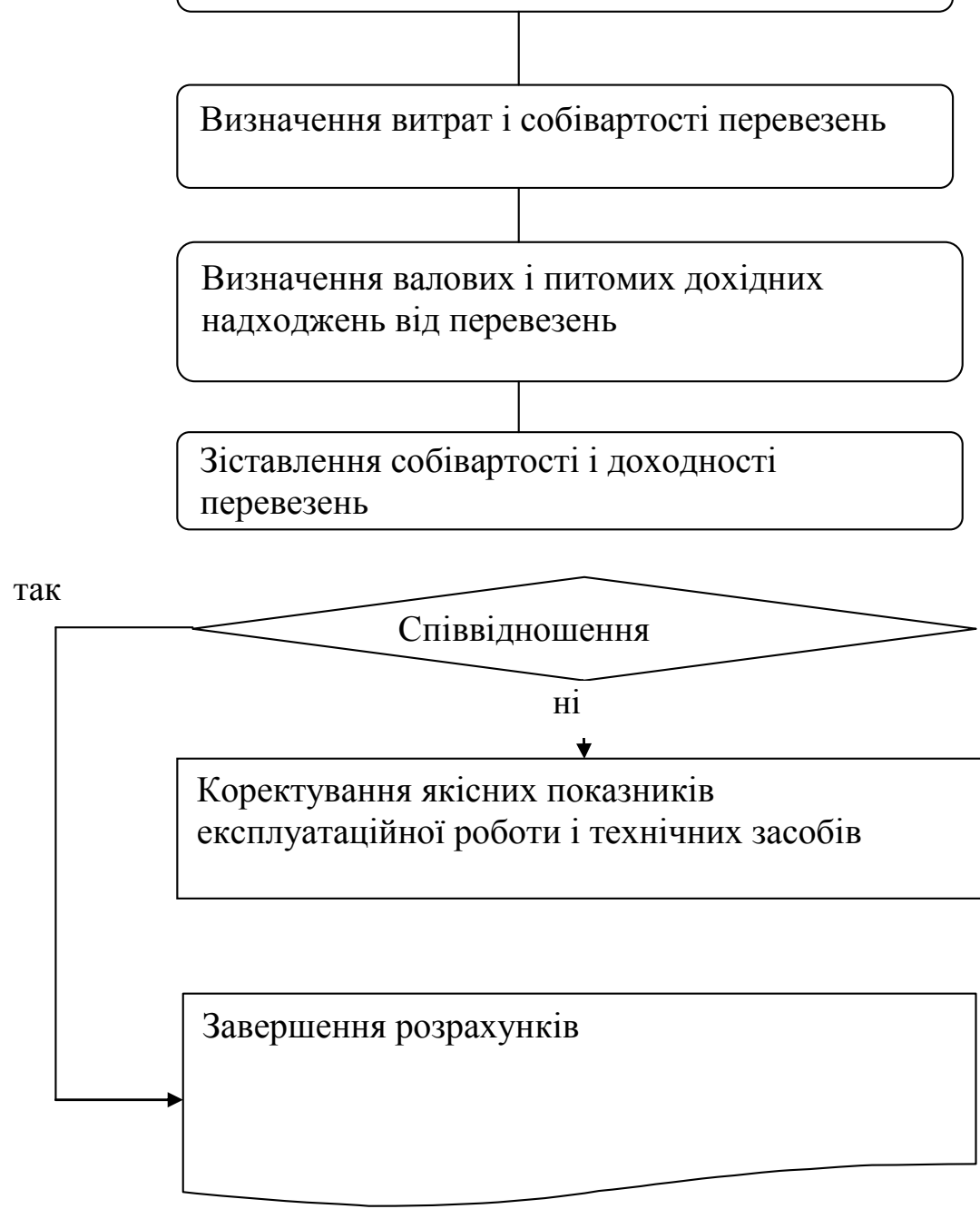

Рис. Алгоритм комплексного планування результатів перевізної діяльності

Якщо ж ці витрати будуть компенсовані додатковими доходами від перевезень, співвідношення собівартості і прибутковості покращиться. Якщо ж ні - відбудеться його погіршення і буде потрібно піти на погіршення параметрів якості перевезень в "обмін" на економію витрат.
Таким чином, наведений на рисунку алгоритм дає змогу пов'язати на етапі планування собівартість і прибутковість роботи залізниці i, виходячи зі співвідношення між ними, оптимізувати якісні показники експлуатаційної роботи й використання технічних засобів, а в перспективному періоді розвиток техніко-технологічної бази залізниці. 
Загальний огляд динаміки собівартості перевезень у короткостроковому періоді починається з оцінки впливу основних факторів на іï зміну порівняно $з$ аналогічним періодом минулого року.

Для цього по кожному господарству потрібно знайти еталонне співвідношення вимірників його роботи і обсягу перевезень. Це можна зробити або статистичним методом на основі порівняння фактичних співвідношень по залізницям (3 урахуванням об'єктивних відмінностей), або аналітичним, виходячи 3 прогресивних нормативів якісних показників, або за допомогою їх поєднання - визначати 3 урахуванням кращих фактичних досягнень еталони якісних показників і на їх основі еталонну величину об'ємних вимірників господарств у розрахунку на одиницю перевізної роботи. Еталонна величина залежних витрат по кожному господарству повинна визначатися як добуток еталонного значення вимірювача на еталонні питомі витрати в залежній частині, що припадають на одиницю вимірювача. Еталонні питомі витрати в залежній частині на одиницю вимірювача повинні визначатися на основі еталонних питомих витрат за групами лінійних підприємств даного господарства та питомою вагою робіт, виконуваних в умовах, відповідних певній групі.

Еталон постійних витрат по господарству повинен бути визначений виходячи 3 оптимального рівня заповнення виробничих потужностей i еталонних питомих постійних витрат на одиницю виробничої потужності, що визначаються за групами підприємств та питомою вагою кожної групи підприємств у роботі господарства.

При розподілі видатків на залежні i постійні для цілей нормування відсоток залежних повинен визначатися не для річного, а для перспективного варіанта, так як планування (i нормування) витрат здійснюється 3 урахуванням багаторічної динаміки і зміни виробничих потужностей.

Мінімізація витрат по кожному господарству окремо також може не забезпечувати мінімуму витрат залізниці (мережі). Тому на основі нормативів витрат, визначених за лінійними підприємствами і господарствами, повинні бути визначені еталонні витрати за операціями перевізного процесу (початковокінцевої i служби перевезень), відповідні оптимальній організації перевізного процесу в цілому i, за цієї умови, оптимальній роботі господарств і лінійних підприємств.

Висновки 3 дослідження і перспективи, подальший розвиток у даному напрямку. Таким чином, на основі еталонних витрат окремих господарств i економічно обгрунтованої оптимізації перевізного процесу в цілому визначаються еталонні витрати за операціями перевізного процесу в цілому по залізницях і мережі.

При збільшенні обсягу перевезень загальна сума експлуатаційних витрат збільшується, але повільніше, ніж обсяг перевезень. Залежність експлуатаційних витрат від обсягу перевезень - пряма уповільнена. Ступінь зміни собівартості перевезень від обсягу роботи визначається співвідношенням питомої ваги залежних і умовно-постійних витрат [1].

Визначення залежності експлуатаційних витрат і собівартості від обсягу перевезень проводиться для трьох варіантів аналізу:

- поточний (річний, квартальний) варіант враховує зміну витрат, що відбивається у фінансовій звітності даного періоду. Питома вага залежних витрат коливається в межах 25-40 \%;

- основний варіант аналізу передбачає, що зміна обсягу перевезень відбувається при незмінних величинах пропускної спроможності залізниць, якісних показників використання рухомого складу, норм витрати паливноенергетичних та інших видів ресурсів. До змінних у цьому варіанті належить весь перелік витрат, безпосередньо пов'язаних 3 обсягом перевезень і мінливих при його зміні прямо пропорційно обсягу перевезень. Питома вага залежних витрат становить $40-55 \%$;

- перспективний варіант з розвитком пропускної спроможності і зміною якісних показників використання рухомого складу і викаткових норм враховуе зміну частини умовнопостійних витрат, в результаті чого питома вага змінних витрат збільшиться до $55-70 \%$.

\section{Список використаних джерел}

1. Макаренко, М.В. Витрати на залізничному транспорті: аналіз і управління [Текст] / М.В. Макаренко, М.Ю. Гончаров, Н.С. Соколовська; за ред. М. В. Макаренка. - К.: ВАТ «УКТП Центр», 2002. - 206 с. 
2. Потетюєва, М.В. Особливості управління витратами на залізничному транспорті [Текст] /М.В. Потетюєва // Залізничний трансп. України. - 2008. - № 2. - С. 76-78.

3. Лапидус, Б.М. Управление издержками: эталонный подход [Текст] / Б.М. Лапидус // Железнодорожный транспорт. - 1998. - № 5. - С.22-23.

4. Полішко, Т.В. Управління витратами підприємств залізничного транспорту [Текст]: автореф. дис... канд. екон. наук: спец. 08.07.03 «Економіка та управління національним господарством» / Т.В. Полішко. - Харків, 2004. - 20 с.

5. Терёшина, Н.П. Оценка транспортных затрат и повышение конкурентоспособности железнодорожных перевозок [Текст] / Н.П. Терёшина // Труды МИИТ. - М.: МИИТ, 1993. Вып. 882. - С. 57-59.

6. Сергієнко, М.М. Системно-ситуаційне управління витратами локомотивного господарства залізничного транспорту [Текст]: автореф. дис... канд. екон. наук: спец. 08.07.04 «Економіка транспорту та зв'язку» / М.М. Сергієнко. - К., 2007. - 20 с.

7. Макаренко, М.В. Совершенствование методики экономической оценки эксплуатационной работы железных дорог в современных условиях [Текст] / М.В. Макаренко, В.И. Пасечник, Н.С. Соколовская // Сборник трудов ИКТП - Центра. К., 1998. - Вып. 5.

8. Козир, О.М. Система управління витратами підприємств залізничного транспорту [Текст]: автореф. дис... канд. екон. наук: спец. 08.00.04 «Економіка та управління підприємствами» / О.М. Козир. - Харків, 2008. - 17 с.

9. Drury, C. Management and Cost Accounting.- 3-rd ed. [Текст] / C. Drury. - London. - Cengage Learning EMEA, 2008. - 775 p.

10. Економічний аналіз [Текст]: навч. посібник / М.А. Болюх [та ін.]; ред. М.Г. Чумаченко; Київський національний економічний ун-т. - К.: КНЕУ, 2001. - 540 с.

Рецензент д-р екон. наук, професор О.Г. Дейнека

Архіпкіна Світлана Юріївна, магістрант. E-mail: Swwetlana@yandex.ru.

Arkhipkina Svetlana, Master's Student. E-mail: Swwetlana@yandex.ru. 